\title{
Inflammatory cell number and mediators in bronchoalveolar lavage fluid and peripheral blood in subjects with asthma with increased nocturnal airways narrowing
}

\author{
Y. Oosterhoff, MD, a H. F. Kauffman, PhD, ${ }^{b}$ B. Rutgers, BSC, ${ }^{a}$ \\ F. J. Zijlstra, PhD, ${ }^{c}$ G. H. Koëter, MD, ${ }^{a}$ and D. S. Postma, MD, ${ }^{a}$ \\ Rotterdam and Groningen, The Netherlands
}

\begin{abstract}
Background: Increased noctumal airways narrowing (NAN) in asthma is thought to occur as the result of intensification of inflammatory processes in the airways. In this study we investigated the presence of inflammatory cells and mediators in bronchoalveolar lavage $(B A L)$ fluid and peripheral blood $(P B)$ and assessed their relationship with the occurrence of increased NAN.

Methods: BAL fluid and PB samples were assessed at 16:00 and 04:00 hours, separated by 7 days or more, in eight nonatopic healthy subjects (group 1) and 17 atopic subjects with asthma who were using inhaled bronchodilators only. The latter subjects were prospectively assigned to groups with and without NAN, as defined by a mean circadian peak expiratory flow variation of less than $15 \%$ (group 2) and $15 \%$ or more (group 3), respectively.

Results: Significantly higher eosinophil numbers and inflammatory activation products (eosinophil cationic protein, eosinophil-derived neurotoxin, histamine) were found in BAL fluid and PB from subjects with asthma in comparison with control subjects. However, increased NAN was not generally associated with a circadian fluctuation in cell number and inflammatory mediators in BAL fluid and PB. No differences in inflammatory cell numbers existed that distinguished between groups 2 and 3. However, in group 3 significantly higher $B A L$ prostaglandin $D_{2}$ levels ( $70 \mathrm{vs} 24 \mathrm{pg} / \mathrm{ml}$; range, 28 to $102 \mathrm{vs} 11$ to $90 \mathrm{pg} / \mathrm{ml} ; \mathrm{p}=0.04$ ) and serum eosinophil cationic protein levels (17.6 vs $16.1 \mathrm{ng} / \mathrm{ml}$; range, 6.3 to $17.5 \mathrm{vs} 6.3$ to $60.3 \mathrm{ng} / \mathrm{ml} ; \mathrm{p}=0.03$ ) at 16:00 hours were detected compared with group 2.

Conclusions: Our findings suggest that increased NAN is more likely to occur in subjects with asthma with ongoing increased cellular activation during the day. (J ALLERGY CLIN IMMUNOL 1995;96:219-29.)
\end{abstract}

Key words: Nocturnal asthma, circadian peak expiratory flow variation, bronchoalveolar lavage, peripheral blood leukocytes, eosinophils; $\mathrm{EG}_{2}{ }^{+}$cells, eosinophil cationic protein, eosinophil-derived neurotoxin, histamine, prostaglandin $\mathrm{D}_{2}$, thromboxane $\mathrm{B}_{2}$, eicosanoids

Increased nocturnal airways narrowing (NAN) in asthma is thought to occur as the result of intensification of inflammatory processes in the

From the Departments of aPulmonology and ${ }^{b}$ Allergology, University Hospital, Groningen, and the 'Department of Pharmacology, Faculty of Medicine, Erasmus University Rotterdam.

Supported by grant 89.15 from the Nederlands Astma Fonds.

Received for publication Sept. 2, 1994; revised April 11, 1994; accepted for publication Nov. 15, 1994.

Reprint requests: D. S. Postma, MD, Department of Pulmonology, University Hospital, Oostersingel 59, 9713 EZ Groningen, The Netherlands.

Copyright (ㅅ) 1995 by Mosby-Year Book, Inc.

$0091-6749 / 95 \$ 3.00+0 \quad \mathbf{1 / 1 / 6 2 0 6 5}$ airways of subjects with nocturnal asthma, as has been suggested by an increase in (indirect) airways hyperresponsiveness at night ${ }^{1}$ and findings that adequate antiinflammatory treatment with inhaled corticosteroids reduce the circadian variation in airways obstruction and responsiveness. ${ }^{2}$

Inflammatory conditions may be associated with an increased influx of cells into the airway wall, together with marked shifts in cell populations in the bronchoalveolar lavage (BAL) fluid. So far, however, conflicting results have been reported as to nocturnal increases in cell numbers and morphology, as analyzed in BAL fluid from subjects with nocturnal asthma. ${ }^{3,4}$ In addition, peripheral 


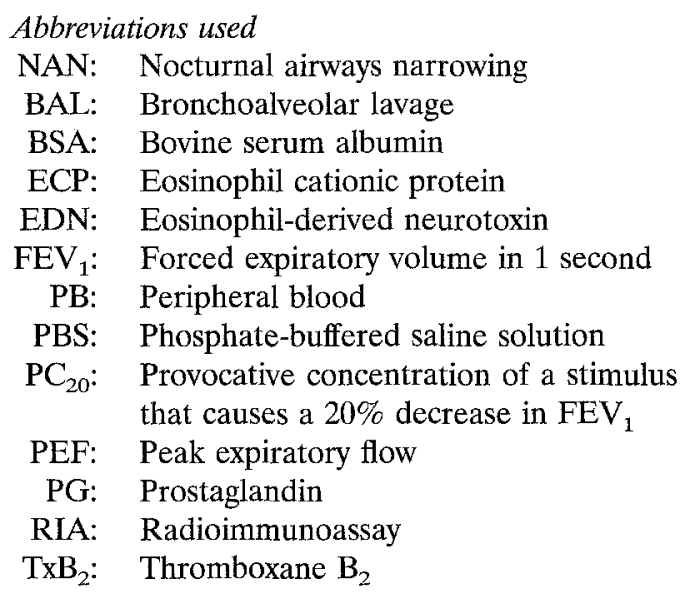

blood (PB) eosinophil numbers and their activation parameters during the night in subjects with nocturnal asthma have been found to be either increased ${ }^{5,6}$ or decreased, ${ }^{7}$ and conflicting results have been reported as to PB histamine levels as well. ${ }^{7,8}$ From the various studies it can often not be deduced whether the circadian variations are due to pathologic processes underlying nocturnal asthma or whether they belong to normal physiologic circadian rhythms. For instance, both in normal and asthmatic subjects circadian rhythms exist in PB leukocyte number and their functional activity. ${ }^{9}$ Similar chronobiologic rhythms in cell number and activity in the airways can be postulated. So far, however, circadian variations in inflammatory cells in BAL fluid of healthy persons have scarcely been investigated.

The aim of this study was to investigate the presence of inflammatory cells and mediators in BAL fluid and PB at 16:00 and 04:00 hours from healthy subjects and from atopic patients with asthma and to determine their relationship with the occurrence of increased NAN in asthma, as assessed by measurement of the circadian peak expiratory flow (PEF) rhythm. Eosinophils and mast cells are considered as principal effector cells. ${ }^{10,11}$ Their activation parameters, as assessed by $\mathrm{EG}_{2}{ }^{+}$-staining cells, eosinophil cationic protein (ECP), eosinophil-derived neurotoxin (EDN), histamine, and prostanoids, have been found to be increased in the BAL fluid of patients with stable and symptomatic asthma. ${ }^{12-16}$ These cell types and activation parameters were assessed in BAL fluid, whereas in PB eosinophil numbers and ECP levels were determined.

\section{METHODS Subjects}

Eight healthy subjects and 17 subjects with asthma (age range, 18 to 45 years) participated in the study (Table I). The subjects were recruited through advertisements in local newspapers and from the outpatient clinic of our hospital. The study was approved by the ethical committee of the hospital, and written informed consent was given by each subject.

At entry to the study the selected healthy volunteers had no history of lung disease or allergy; no atopy, as demonstrated by negative results of intracutaneous tests against 18 common aeroallergens, expressed as histamine equivalent wheal size less than 0.7 (Diephuis Laboratories, Groningen, The Netherlands); no airway response on provocation with methacholine, as determined by a fall in forced expiratory volume in 1 second $\left(\mathrm{FEV}_{1}\right)$ of less than $10 \%$ after inhalation of methacholine bromide in a concentration of $9.8 \mathrm{mg} / \mathrm{ml}$ (2-minute inhalation, 5-minute interval); and no upper respiratory infections within 1 month before the study and no concomitant diseases.

Subjects with asthma were prospectively selected on the basis of a history of episodic dyspnea or wheezing consistent with the clinical diagnosis of asthma ${ }^{17}$; atopy, as determined by positive results of intracutaneous tests against house dust mite or two of 18 other tested common aeroallergens (histamine equivalent wheal size $\geq 0.7) ; \mathrm{FEV}_{1}$ greater than $1.50 \mathrm{~L}$ and $70 \%$ or more of predicted value; postbronchodilator $\mathrm{FEV}_{1}(400 \mu \mathrm{g}$ salbutamol with a spacehaler) $80 \%$ or more of predicted value; airway hyperresponsiveness to methacholine, defined as the provocative concentration of methacholine bromide that caused a $20 \%$ fall in $\mathrm{FEV}_{1}\left(\mathrm{PC}_{20}\right)$ of 9.8 $\mathrm{mg} / \mathrm{ml}$ or less (2-minute inhalation, 5-minute interval); no use of oral corticosteroids within 2 months before the study; no upper respiratory infections within 1 month before the study and no other concomitant diseases.

\section{Study design}

In the subjects with asthma inhaled corticosteroids and cromolyns were stopped 4 weeks before the start of the study. Until the last bronchoscopy subjects were allowed to use inhaled bronchodilators only ( $\beta_{2}$-agonists or ipratropium bromide).

The week before the study PEF values were recorded for 3 days at 08:00, 12:00, 16:00, 20:00, 24:00, and 4:00 hours. Bronchodilators were withheld. The best of three PEF maneuvers was recorded. The mean circadian PEF variation of the 3 days was defined as (Highest 24 Hour Value - Lowest 24-Hour Value) $\div$ Mean 24-Hour Value. Subjects were prospectively selected in three groups: group 1 consisted of healthy volunteers, whereas subjects with asthma were assigned to group 2 if the mean circadian PEF variation was less than $15 \%$ and to group 3 if the PEF variation was $15 \%$ or greater. Nocturnal asthma symptoms were scored on the basis of 
TABLE I. Subject characteristics

\begin{tabular}{|c|c|c|c|c|c|c|c|c|}
\hline & $\begin{array}{l}\text { Age (yr)/ } \\
\text { gender }\end{array}$ & $\begin{array}{l}\text { Smoking } \\
\text { history }\end{array}$ & Medication* & $\begin{array}{l}\text { No. of } \\
\text { positive } \\
\text { skin test } \\
\text { results }\end{array}$ & $\begin{array}{c}\text { FEV } \\
\text { (\% predicted) }\end{array}$ & $\begin{array}{c}\mathrm{PC}_{20} \\
\text { methacholine } \\
(\mathrm{mg} / \mathrm{ml})\end{array}$ & $\begin{array}{l}\text { NAN } \\
\text { scoret }\end{array}$ & $\begin{array}{c}\text { PEF rhythm } \\
(\%) \neq\end{array}$ \\
\hline \multicolumn{9}{|c|}{ Group 1 (Subject No.) } \\
\hline 1 & $44 / \mathrm{M}$ & - & - & 0 & 121 & $>9.8$ & - & 4 \\
\hline 2 & $21 / \mathbf{F}$ & - & - & 0 & 107 & $>9.8$ & - & 6 \\
\hline 3 & $20 / \mathrm{M}$ & - & - & 0 & 88 & $>9.8$ & - & 8 \\
\hline 4 & $32 / \mathrm{M}$ & - & - & 0 & 92 & $>9.8$ & - & 8 \\
\hline 5 & $27 / \mathbf{F}$ & - & - & 0 & 99 & $>9.8$ & - & 9 \\
\hline 6 & $21 / \mathrm{M}$ & - & - & 0 & 116 & $>9.8$ & - & 9 \\
\hline 7 & $34 / F$ & - & - & 0 & 125 & $>9.8$ & - & 11 \\
\hline 8 & $22 / \mathrm{F}$ & - & - & 0 & 93 & $>9.8$ & - & 11 \\
\hline \multicolumn{9}{|c|}{ Group 2 (Subject No.) } \\
\hline 1 & $30 / \mathrm{M}$ & - & B & 7 & 100 & 1.33 & 0 & 6 \\
\hline 2 & $20 / \mathrm{M}$ & - & $\mathrm{B}$ & 6 & 105 & 1.88 & 0 & 8 \\
\hline 3 & $19 / \mathrm{M}$ & - & $\mathrm{CR}$ & 6 & 80 & 1.64 & 0 & 10 \\
\hline 4 & $22 / \mathrm{F}$ & - & B & 7 & 90 & 0.34 & 1 & 11 \\
\hline 5 & $18 / \mathrm{M}$ & - & $\mathrm{B}, \mathrm{CS}$ & 6 & 82 & 0.63 & 0 & 12 \\
\hline 6 & $29 / \mathrm{F}$ & - & $\mathrm{B}, \mathrm{CS}$ & 6 & 97 & 1.68 & 0 & 13 \\
\hline 7 & $40 / \mathrm{M}$ & - & B & 7 & 94 & 0.36 & 1 & 14 \\
\hline \multicolumn{9}{|c|}{ Group 3 (Subject No.) } \\
\hline 1 & $41 / \mathrm{M}$ & - & A & 2 & 114 & 0.73 & 0 & 19 \\
\hline 2 & $22 / \mathrm{M}$ & - & $\mathrm{B}, \mathrm{CS}$ & 8 & 90 & 0.66 & 1 & 20 \\
\hline 3 & $22 / \mathrm{F}$ & - & $\mathrm{B}, \mathrm{CS}$ & 7 & 69 & 0.04 & 1 & 23 \\
\hline 4 & $32 / \mathrm{F}$ & - & $\mathrm{A}, \mathrm{CS}$ & 3 & 94 & 0.60 & 1 & 24 \\
\hline 5 & $29 / \mathrm{M}$ & - & B & 4 & 80 & 0.64 & 0 & 25 \\
\hline 6 & $21 / \mathrm{F}$ & - & B & 2 & 98 & 0.96 & 1 & 28 \\
\hline 7 & $21 / \mathrm{F}$ & + & B & 8 & 68 & 0.08 & 1 & 29 \\
\hline 8 & $26 / \mathrm{F}$ & + & $\mathrm{B}, \mathrm{CS}$ & 8 & 82 & 0.17 & 1 & 31 \\
\hline 9 & $41 / F$ & - & $\mathrm{B}, \mathrm{CS}$ & 7 & 92 & 0.37 & 2 & 44 \\
\hline 10 & $20 / \mathrm{F}$ & - & $\mathrm{B}, \mathrm{CR}$ & 5 & 88 & 0.04 & 2 & 46 \\
\hline
\end{tabular}

$A$, Anticholinergic drugs; $B, \beta_{2}$-adrenergic drugs; $C R$, cromoglycate; $C S$, corticosteroid.

${ }^{*}$ Regular inhaled therapy until 4 weeks before participation in the study.

†Awakening because of nocturnal dyspnea: $0=$ never, $1=$ sometimes, $2=$ every night in previous 2 weeks.

$\ddagger$ Expressed as (Highest 24-Hour Value - Lowest 24-Hour Value) $\div$ Mean 24-Hour Value.

nocturnal awakening caused by nocturnal dyspnea in the last week, as follows: $0=$ never, $1=$ sometimes, $2=$ every night. $\mathrm{FEV}_{1}$ and airway hyperresponsiveness to methacholine were assessed within 5 days before the first bronchoscopy.

Thirty minutes before each bronchoscopy, $\mathrm{FEV}_{1}$ measurements were performed and PB samples were taken. Subjects rested for 15 minutes before the daytime lung function measurements. At night subjects were admitted to the hospital at 22:00 hours and were awakened 15 minutes before the measurements. Bronchodilator therapy was withheld 8 hours before the pulmonary function tests. Bronchoscopy was performed at 16:00 hours (4:00 PM) and 04:00 hours (4:00 AM) on two different days, separated by at least 7 days. Nineteen subjects underwent their first bronchoscopy at 16:00 hours, and five at 04:00 hours.

\section{Pulmonary function and inhalation provocation tests}

PEF values were recorded with a Wright mini peak flow meter. FEV 1 was measured with a calibrated watersealed spirometer according to standardized guidelines, ${ }^{18}$ with the best of three measurements being used for analysis. Airway responsiveness to methacholine was measured by a 2 -minute tidal breathing method. ${ }^{19}$ Provocative concentration of a stimulus that causes a $20 \%$ decrease in $\mathrm{FEV}_{1}\left(\mathrm{PC}_{20}\right)$ were calculated by linear interpolation of the last two points of the log concentration response curve.

\section{Bronchoscopy procedure}

Fiber-optic bronchoscopy was undertaken according to guidelines described by the American Thoracic Society. ${ }^{20}$ Premedication consisted of intramuscular injec- 
tion of $0.5 \mathrm{mg}$ atropine and inhalation of $200 \mu \mathrm{g}$ salbutamol via a Volumatic spacer device (Glaxo, Utrecht, The Netherlands). Lidocaine $4 \%$ was applied as local anesthetic into the upper airways and bronchial tree. Supplementary oxygen was available. Bronchoscopy was performed with an Olympus B1 IT10 flexible fiber-optic bronchoscope (Olympus Optical Co., Tokyo, Japan). The instrument was inserted through the mouth and wedged in the lateral segment of the right middle lobe. Subsequently, 10 aliquots of $20 \mathrm{ml}$ sterile phosphate-buffered saline solution (PBS) of $37^{\circ} \mathrm{C}$ were instilled and recovered by gentle suction $\left(-40 \mathrm{~cm} \mathrm{H}_{2} \mathrm{O}\right)$ after each aliquot. The BAL fluid was collected in polypropylene tubes, which were immediately placed in ice.

\section{Laboratory techniques}

The BAL fluid was pooled in two fractions: pool 1 consisted of the fluid recovered from the first two $20 \mathrm{ml}$ quantities of PBS instilled, which contained constituents from the proximal airways; pool 2 comprised the fluid from the remaining 8 quantities of $20 \mathrm{ml}$. Cell numbers and activation parameters were assessed in the first fraction. Because of a limited amount of BAL fluid in this fraction, the eicosanoids had to be determined in pool 2. The lavage fluid was filtered through a $100 \mu \mathrm{m}$ pore filter of a venous infusion system (Curapharm, Medica B.V., Hospital Supplies, Hertogenbosch, The Netherlands) to remove mucus and centrifuged at $400 \mathrm{~g}$ at $4^{\circ} \mathrm{C}$ for 5 minutes. The BAL supernatant was stored at $-80^{\circ} \mathrm{C}$ until further determination. The cell pellets were resuspended in $1 \mathrm{ml}$ PBS with $0.5 \%$ heat-inactivated bovine serum albumin (BSA) (PBS/BSA 0.5\%).

Total leukocyte counts in PB and BAL cell suspensions were measured in a Coulter Counter (model S-plus VI; Coulter Electronics, Hialeah, Fla.), and viability was assessed by cellular exclusion of trypan blue. Cytocentrifuged preparations of both pools of BAL fluid were made from $100 \mu \mathrm{l}$ fractions of the BAL cell suspension, diluted to a volume of $0.25 \times 10^{6}$ cells $/ \mathrm{ml}$ in PBS/BSA, $0.5 \%$, with a Shandon Cytospin-2 centrifuge (Shandon Inc., Pittsburgh, Pa.). After preparations were stained with May-Grünwald-Giemsa, the average of 300 cell counts on two slides was taken as the differential cell count. Additional cytocentrifuged preparations were sealed in plastic and stored at $-80^{\circ} \mathrm{C}$ for future staining and analysis. $\mathrm{PB}$ eosinophil numbers were counted in a Bürker chamber after staining with eosin.

Activated eosinophils in the BAL fluid were identified by immunostaining of acetone-fixed cytocentrifuge preparations with the monoclonal antibody $\mathrm{EG}_{2}$ (Sanbio, Uden, The Netherlands), which detects a cleaved part of the ECP. A two-step alkaline phosphatase procedure was performed, according to the method described by Tai et al., ${ }^{21}$ with minor modifications. The slides were incubated with $50 \mu \mathrm{lEG}_{2}$ solution (1:50) for 60 minutes. As a control for false-positive counting, the primary antibody was omitted or an irrelevant antibody was used as a first step. The slides were then incubated for 30 minutes with an alkaline phosphatase-conjugated rabbit anti-mouse IgG antibody (1:40) (Sigma, St. Louis, Mo.) supplemented with $5 \%$ human $\mathrm{AB}$ serum, followed by an alkaline phosphatase-conjugated goat anti-rabbit IgG antibody (1:40) supplemented with $5 \%$ human $\mathrm{AB}$ serum. The phosphatase reactivity was demonstrated by Fast Red (Sigma) $(1 \mathrm{mg} / \mathrm{ml})$ in tris(hydroxymethyl) aminomethene-HCl buffer, $0.1 \mathrm{~mol} / \mathrm{L} \mathrm{pH} \mathrm{8.2;} \mathrm{containing}$ $0.2 \mathrm{mg} / \mathrm{ml}$ naphthol AS-MX (Sigma) with $2 \mathrm{mmol} / \mathrm{L}$ levamisole (Sigma) to inhibit endogenous alkaline phosphatase. The slides were counterstained with fresh Mayers' hematoxylin. $\mathrm{EG}_{2}{ }^{+}$cell counts were performed on two slides and the average counts of 500 cells on each slide was taken as the definitive number of positive cells. Only intact and unclustered cells were counted. Total $\mathrm{EG}_{2}{ }^{+}$cell counts were calculated from the total leukocyte number per milliliter of BAL fluid.

$E C P$ and EDN determination in serum and BAL fluid. Serum was obtained after coagulation of the blood for 1 hour at room temperature. The supernatant was centrifuged twice for 10 minutes at $2000 \mathrm{~g}$ and stored at $-80^{\circ} \mathrm{C}$ until analysis. ECP was measured in serum, whereas ECP and EDN were determined in unprocessed BAL supernatants from pool 1 . This was performed by double-antibody radioimmunoassays (RLA) (Pharmacia Diagnostics AB, Uppsala, Sweden), as described previously. ${ }^{22,23}$ The detection level in both assays was 0.1 $\mathrm{ng} / \mathrm{ml}$.

Histamine determination in BAL fluid. Histamine was determined in unprocessed lavage supernatants from pool 1, with the RIA procedure from Immunotech (Westbrook, Maine), in accordance with the manufacturer's protocol.

Eicosanoid determination. Immediately after the BAL procedure $20 \mathrm{ml}$ of BAL supernatant from pool 2 was processed on C18 SepPak cartridges (Millipore, Bedford, Mass.) as described previously ${ }^{24}$ eluted with $2.5 \mathrm{ml}$ methanol and stored at $-80^{\circ} \mathrm{C}$ until analysis. Samples of $200 \mu$ l eluted fluid were pipetted into polypropylene tubes and dried with a Savant sample concentrator. After dissolving in $300 \mu$ l assay buffer, thromboxane $B_{2}$ $\left(\mathrm{TxB}_{2}\right)$ level was determined by means of a $\left[{ }^{3} \mathrm{H}\right] \mathrm{RIA}$ with antisera from Advanced Magnetics Inc. (Cambridge, Mass.) and tritium-labeled compounds from Amersham International plc. (Amersham, Buckinghamshire, U.K.; prostaglandin (PG) $\mathrm{D}_{2}$ and $\mathrm{PGF}_{2 \alpha}$ were tritium-labeled kits obtained from Amersham UK. ${ }^{24}$ 6-Keto $\mathrm{PGF}_{1 \alpha}\left(6 \mathrm{kPGF}_{1 \alpha}\right)$ was determined by means of a iodine 125-labeled RIA kit (Du Pont de Nemours, Dreieich, Germany). Leukotriene $\mathrm{C}_{4} / \mathrm{D}_{4} / \mathrm{E}_{4}$ was measured at room temperature in a microtiter enzyme immunoassay according to protocol (Biotrak, Amersham, UK). Crossreactivities for each assay to related compounds were negligible or less than $2 \%$ at $\mathrm{B} / \mathrm{Bo} 50 \%$.

\section{Data analysis}

$\mathrm{PC}_{20}$ values were analyzed after base 2 logarithmic transformation and expressed as the geometric mean 
$\mathrm{PC}_{20}$ value. After verification of the normal distribution, changes in values of lung function parameters within subjects were analyzed with the Student paired twotailed $t$ test and between groups with the Student $t$ test for unpaired observations. Nonparametric tests were used to analyze the cell number and activation parameters, the number of positive skin test results, and nocturnal asthma score. The Mann-Whitney $U$ test was used to compare data between groups, and Wilcoxon's matched signed-rank test was applied for within-group analyses. Correlations between the circadian PEF variations, and lung function or cell parameters, were made by Spearman's rank correlation tests. All analyses were performed with the SPSS/PC ${ }^{+}$V 4.01 software package (SPSS Inc., Chicago, Ill.). Values of $p 0.05$ or less were considered statistically significant.

\section{RESULTS \\ Subjects}

Subject characteristics are listed in Table I. Group 1 consisted of healthy volunteers. Seven subjects with asthma were assigned to group 2 (mean circadian PEF variation, $<15 \%$ ) and 10 to group 3 (mean circadian PEF variation, $\geq 15 \%$ ). Mean circadian PEF rhythms in the control group and group 2 were not significantly different from each other. Age and gender were not significantly different among the three groups, nor were the number of positive skin test results and mean percentage of predicted $\mathrm{FEV}_{1}$ between the two asthma groups. Mean percentage of predicted $\mathrm{FEV}_{1}$ was significantly lower in both asthma groups as compared with the healthy control group $(p<0.05)$.

Subjects with asthma in group 3 scored significantly higher on awakening because of nocturnal dyspnea $(p=0.03)$, and their geometric mean $\mathrm{PC}_{20}$ from methacholine was significantly lower as compared with the subjects with asthma in group $2(0.26$ and $0.91 \mathrm{mg} / \mathrm{ml}$, respectively; $p=0.02$ ). The circadian PEF variation of all subjects with asthma was significantly correlated with the $\mathrm{PC}_{20}$ methacholine values $(r=-0.65, p=0.007)$ and with the nocturnal asthma symptom score $(r=0.73$, $p=0.009$ ).

\section{FEV 1 measurements}

Mean $\mathrm{FEV}_{1}$ in group 3 decreased significantly at night as compared with the 16:00 hour value (from $87.5 \% \pm 13.7 \%$ to $75.7 \% \pm 19.2 \%, p=0.005)$, whereas this was less pronounced in group 2 (from $92.6 \% \pm 9.2 \%$ to $88.1 \% \pm 10.1 \%, p=0.09$ ). In the healthy control group no differences were foundbetween the 16:00 and 04:00 hour values (105\% \pm $14.2 \%$ and $105 \% \pm 13.2 \%$, respectively).

\section{Bronchoscopy procedure}

Results of BAL parameters in group 3 are based on data from nine subjects (subject 4 in this group refused a second bronchoscopy).

\section{BAL cell analysis}

The volume of fluid recovered, and total and differential cell numbers, in pool 1 are shown in Table II. The volume of fluid recovered was lower in the asthmatic groups than in the normal volunteers, but this reached significance only at 04:00 hours $(p=0.04)$. Mean total and differential cell numbers per milliliter of BAL fluid were not significantly different among the various groups at the different time points.

Eosinophil numbers were higher in the subjects with asthma as compared with the control group (16:00 hours, $p \leq 0.004 ; 04: 00$ hours, $p=0.05$ ) but were not significantly different between the two asthmatic groups. In groups 1 and 2 the numbers tended to increase at night and ran parallel with increased numbers of neutrophils at 04:00 hours ( $p=0.02$ and $p=0.03$, respectively).

$\mathrm{EG}_{2}{ }^{+}$cell numbers showed the same pattern as the eosinophil numbers (Table II). The numbers were significantly higher in the subjects with asthma than in the control subjects at 16:00 hours $(p<0.001)$, with the same trend at 04:00 hours. No statistical difference was found between both asthmatic groups. The numbers of $\mathrm{EG}_{2}{ }^{+}$cells were always higher at 04:00 hours than at 16:00 hours and reached significance in group $2(p=0.04)$.

\section{BAL inflammatory mediator levels}

In all subjects with asthma EDN and histamine values were higher than in the control group and reached significance at 16:00 hours ( $p=0.04$ and $p=0.003$, respectively) (Fig. 1). There was no statistically significant difference in EDN and histamine levels between the asthma groups at both time points. No significant variation in EDN and histamine levels between 04:00 and 16:00 hours was found in the three groups. In contrast to EDN, most ECP levels were less than the detection level of $0.1 \mathrm{ng} / \mathrm{ml}$ and were therefore not suitable to detect differences between the time points among the various groups.

Eicosanoid levels in BAL fluid are shown in Fig. 2. Because of the limited recovery of BAL fluid, eicosanoid levels could not be assessed in two subjects with asthma, one from group 2 and one from group 3. Significantly higher levels of $\mathrm{PGD}_{2}$ were found in group 3 as compared with the other 
TABLE II. Cellular aspects of BAL fluid (pool 1)

\begin{tabular}{|c|c|c|c|c|c|c|}
\hline \multirow[b]{2}{*}{ Variable } & \multicolumn{2}{|c|}{ Group 1 (control) } & \multicolumn{2}{|c|}{$\begin{array}{l}\text { Group } 2 \text { (asthma with PEF } \\
\text { rhythm }<15 \% \text { ) }\end{array}$} & \multicolumn{2}{|c|}{$\begin{array}{c}\text { Group } 3 \text { (asthma with PEF } \\
\text { rhythm }>15 \% \text { ) }\end{array}$} \\
\hline & $16: 00$ & 04:00 & 16:00 & 04:00 & 16:00 & 04:00 \\
\hline Recovery (\%) & $48.8(37.5-57.5)$ & $47.5(40.0-57.5)$ & $45.0(25.0-57.5)$ & $36.3(22.5-50.0)^{*}$ & $40.0(25.0-55.0)$ & $32.5(17.5-50.0)^{*}$ \\
\hline $\begin{array}{l}\text { Total leukocytes } \\
\left(10^{3} \text { cells } / \mathrm{ml}\right)\end{array}$ & $50.4(8.6-199)$ & $64.3(28.0-87.9)$ & $48.9(26.5-86.7)$ & $68.5(30.7-164)$ & $51.8(25.5-155)$ & $71.0(17.8-249)$ \\
\hline $\begin{array}{l}\text { Alveolar macro- } \\
\text { phages }\left(10^{3}\right. \\
\text { cells } / \mathrm{ml})\end{array}$ & $48.8(7.7-193)$ & $56.7(24.6-72.8)$ & $46.1(24.6-79.5)$ & $64.4(18.4-146)$ & $50.4(19.5-151)$ & $68.0(15.2-171)$ \\
\hline $\begin{array}{l}\text { Mast cells } \\
\qquad\left(10^{3} \text { cells } / \mathrm{ml}\right)\end{array}$ & $0.0(0.0-0.04)$ & $0.0(0.0-0.1)$ & $0.0(0.0-0.05)$ & $0.0(0.0-0.0)$ & $0.0(0.0-0.2)$ & $0.0(0.0-0.0)$ \\
\hline $\begin{array}{l}\text { Lymphocytes } \\
\qquad\left(10^{3} \text { cells } / \mathrm{ml}\right)\end{array}$ & $1.5(0.1-2.6)$ & $1.5(0.0-3.5)$ & $1.4(0.6-2.0)$ & $2.2(0.7-6.0)$ & $0.8(0.0-2.7)$ & $1.0(0.1-2.9)$ \\
\hline $\begin{array}{l}\text { Neutrophils } \\
\qquad\left(10^{3} \text { cells } / \mathrm{ml}\right)\end{array}$ & $0.7(0.3-3.6)$ & $2.9(1.4-14.9) \dagger$ & $0.1(0.0-1.2)$ & $2.5(0.0-6.5) \dagger$ & $0.5(0.0-19.5)$ & $0.2(0.0-7.1)$ \\
\hline $\begin{array}{l}\text { Eosinophils } \\
\qquad\left(10^{3} \text { cells } / \mathrm{ml}\right)\end{array}$ & $0.2(0.0-0.8)$ & $0.6(0.0-5.0)$ & $1.1(0.5-4.6) \ddagger$ & $2.6(1.2-6.7) \div$ & $0.7(0.2-4.0) \ddagger$ & $1.5(0.1-75.1)$ \\
\hline $\begin{array}{l}\mathrm{EG}_{2}^{+} \text {cells } \\
\quad\left(10^{3} \text { cells } / \mathrm{ml}\right)\end{array}$ & $0.1(0.0-0.2)$ & $0.2(0.0-2.6)$ & $0.6(0.1-6.7) \S$ & $2.3(0.7-14.7) \S$ & $0.6(0.1-2.0) \S$ & $1.0(0.0-16.7)$ \\
\hline $\begin{array}{l}\text { Epithelial cells } \\
\qquad\left(10^{3} \text { cells } / \mathrm{ml}\right)\end{array}$ & $0.1(0.0-1.0)$ & $0.1(0.0-3.3)$ & $0.0(0.0-2.1)$ & $0.1(0.0-0.2)$ & $0.1(0.0-2.5)$ & $0.2(0.0-2.8)$ \\
\hline
\end{tabular}

Values expressed as medians, with ranges in parentheses.

*All subjects with asthma, $p=0.04$ compared with 16:00 hour value; $p=0.01$ compared with 4:00 hour value in group 1.

$\dagger p<0.05$ compared with 16:00 hour value within group.

†All subjects with asthma: $16: 00$ hours, $p \leq 0.004$; and 04:00 hours, $p=0.05$, compared with value of control group.

§All subjects with asthma: 16:00 hours, $p<0.001$; and 04:00 hours, $p=0.001$, compared with value of control group.

groups at both time points $(p \leq 0.04)$. Furthermore, $\mathrm{TxB}_{2}$ levels in group 3 were significantly higher as compared with group 2 at both time points $(p=0.04)$, but this did not reach significance as compared with the control group. Increased levels of leukotriene $C_{4}$ were found in group 3 at 04:00 hours as compared with the other groups, reaching significance with the control group $(p=0.03)$. No significant differences in $\mathrm{PGF}_{2 \alpha}$ and $6 \mathrm{kPGF}_{1 \alpha}$ levels were observed among the various groups. No significant variations in eicosanoid levels between 04:00 and 16:00 hours within the three groups were found.

\section{Peripheral blood analysis}

Total leukocyte counts (Table III) did not show a statistically significant difference between normal subjects, all subjects with asthma, or the asthma subgroups at 16:00 and 04:00 hours. Furthermore, there were no variations between 04:00 and 16:00 hours in the three groups.

Eosinophil numbers in PB were significantly higher in all subjects with asthma as compared with the control subjects at 16:00 hours and 04:00 hours $(p \leq 0.01$ ), but there was no significant difference between the two asthma groups. Mean total eo- sinophil counts were increased in all groups at 04:00 hours compared with the 16:00 hour values. This reached significance in group $2(p=$ $0.05)$.

Mean serum ECP level at 16:00 hours were not significantly different between groups 1 and 2, whereas this level was significantly higher in group $3(p \leq 0.03)$. At 04:00 hours levels in both asthma groups were significantly higher than in the control group ( $p \leq 0.01$ ), whereas no significant difference was found between the two asthma groups. Mean serum ECP was significantly increased at night in group $2(p=0.02)$ but not in the other groups.

\section{Correlations with circadian PEF variation in subjects with asthma}

Bronchoalveolar lavage. Eosinophil and $\mathrm{EG}_{2}{ }^{+}$ cell numbers, mast cells, histamine levels, and other eicosanoid levels in the BAL fluid at 16:00 and 04:00 hours and changes between 04:00 and 16:00 hours were not significantly correlated with the circadian PEF variation in subjects with asthma, although a trend was found for higher $\mathrm{PGD}_{2}$ levels at 16:00 hours and for higher EDN levels at 04:00 hours with a bigger circadian PEF 

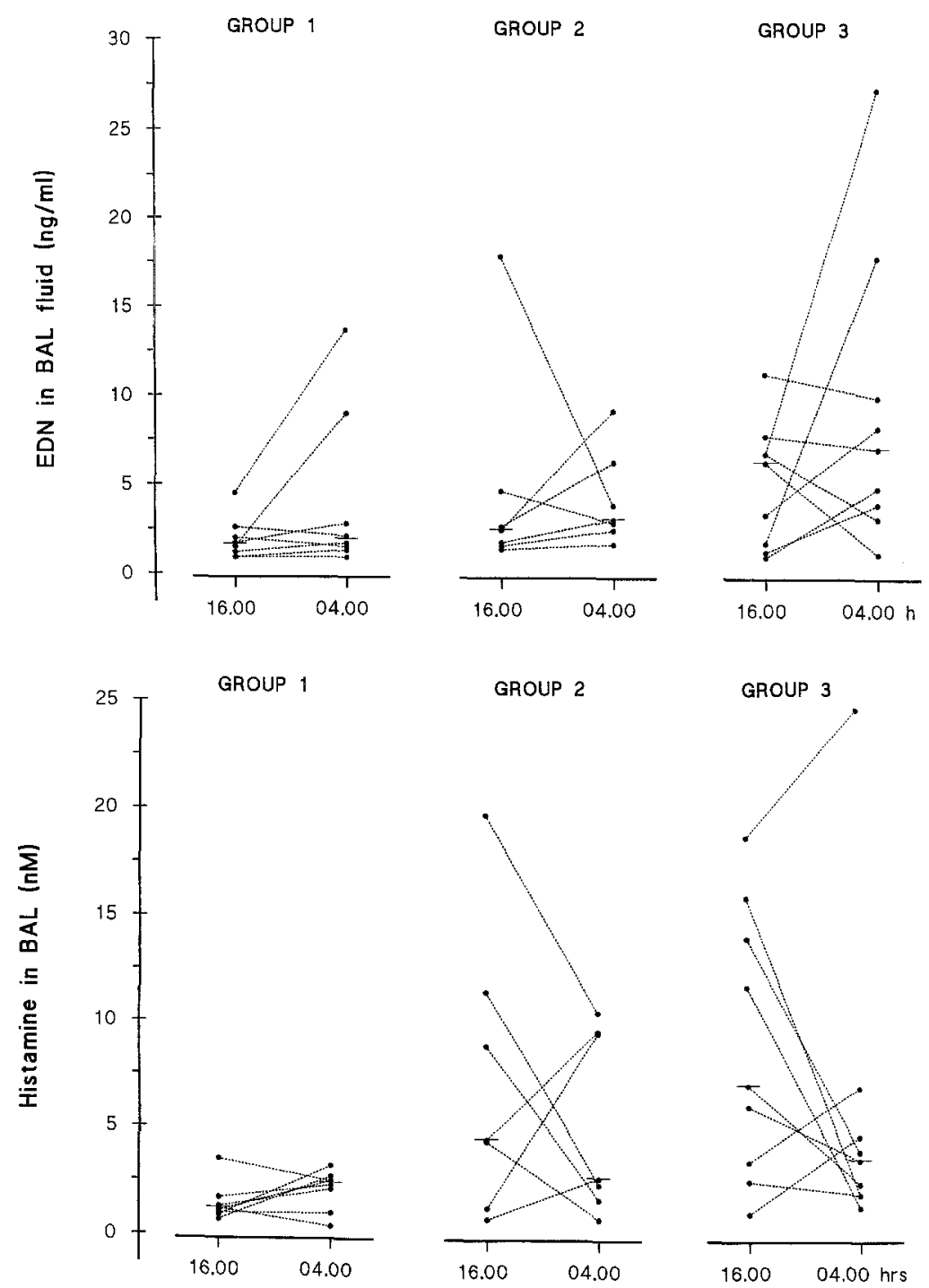

FIG. 1. EDN (upper panel) and histamine (lower panel) levels in BAL fluid (pool 1) at 16:00 and 04:00 hours in control subjects (group 1), and in subjects with asthma with circadian PEF variation less than $15 \%$ (group 2 ) and $15 \%$ or greater (group 3 ). Individual values are represented by dots; median values by horizontal bars. For details, see Results.

rhythm $(r=0.49$ and $r=0.47$, respectively; $p=$ 0.06 ).

Peripheral blood. ECP values at 16:00 hours (also without outlier of 60.3) correlated significantly with the circadian $\mathrm{PEF}$ variation in subjects with asthma $(r=0.61, p=0.01)$ (Fig. 3). Total eosinophil numbers at 16:00 and 04:00 hours, and variations between 04:00 and 16:00 hours, were not significantly correlated with the circadian PEF variation.

\section{DISCUSSION}

We investigated the presence of inflammatory cell numbers and their activation products in BAL fluid and $\mathrm{PB}$ and determined their relationship with the occurrence of increased NAN in asthma, as assessed by measurement of the circadian PEF variation. Overall, higher eosinophil numbers and levels of inflammatory cell activation products were found in BAL fluid and PB from subjects with asthma in comparison with control subjects. However, in subjects with asthma with increased circadian PEF rhythm, no specific circadian change in inflammatory cells and the investigated mediators occurred. Most activation parameters at 16:00 and 04:00 hours did not differentiate this group from subjects with asthma without increased NAN. Interestingly, a number of eicosanoid levels in BAL fluid $\left(\mathrm{PGD}_{2}\right.$ and $\left.\mathrm{TxB}_{2}\right)$ and serum ECP levels were significantly higher in daytime in subjects with 

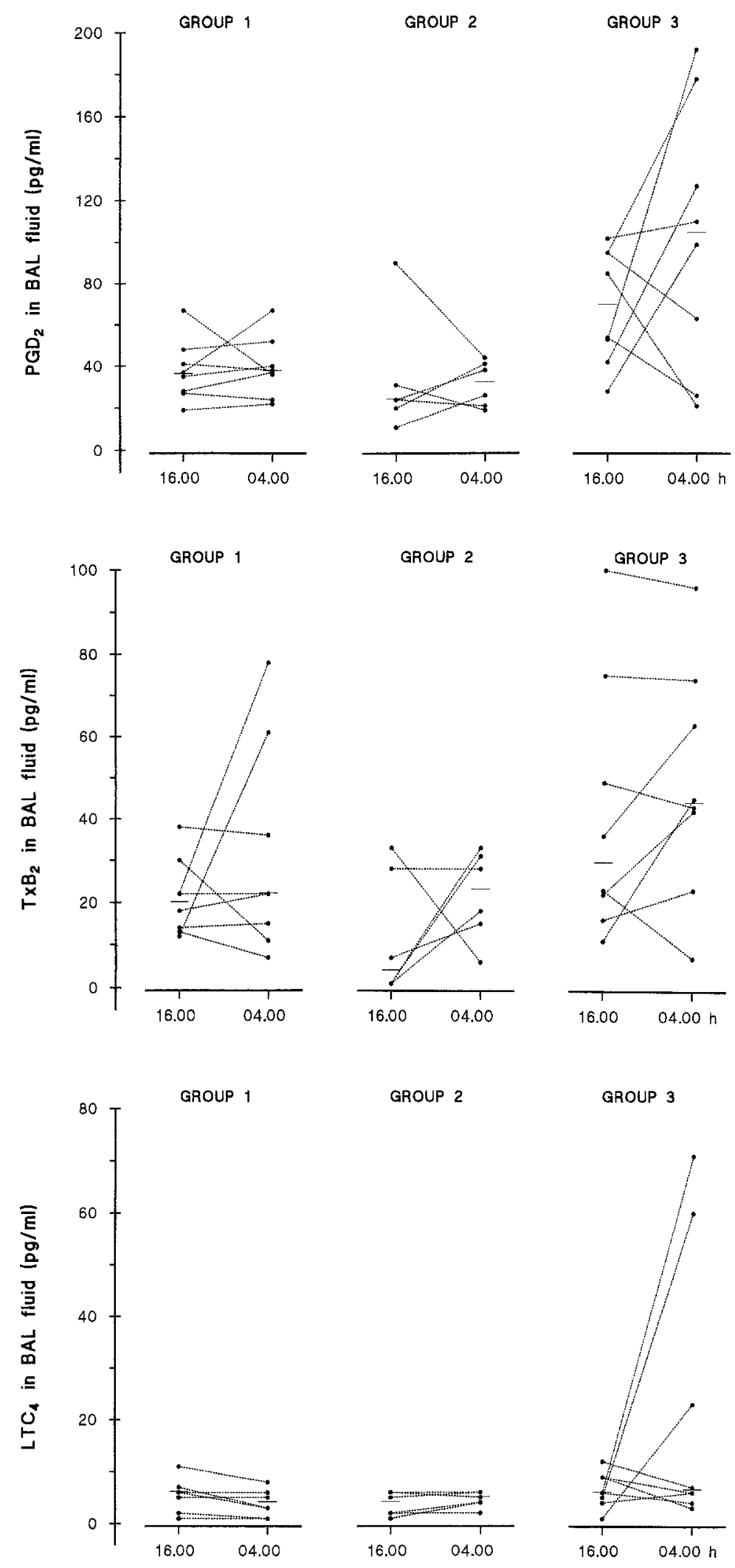

FIG. 2. Eicosanoid levels in BAL fluid (pool 2) at 16:00 and 04:00 hours in control subjects (group 1 ) and in subjects with asthma with circadian PEF variation less than $15 \%$ (group 2) and $15 \%$ or greater (group 3). Individual values are represented by large dots; median values expressed by horizontal bars. For details, see Results. 
TABLE III. Cellular aspects of PB

\begin{tabular}{|c|c|c|c|c|c|c|}
\hline & \multicolumn{2}{|c|}{ Group 1 (control) } & \multicolumn{2}{|c|}{$\begin{array}{l}\text { Group } 2 \text { (asthma with PEF } \\
\text { rhythm }<15 \% \text { ) }\end{array}$} & \multicolumn{2}{|c|}{$\begin{array}{c}\text { Group } 3 \text { (asthma with PEF } \\
\text { rhythm }>15 \% \text { ) }\end{array}$} \\
\hline & $16: 00$ & $04: 00$ & $16: 00$ & $04: 00$ & $16: 00$ & $04: 00$ \\
\hline $\begin{array}{c}\text { Total leukocytes } \\
\left(10^{9} \text { cells } / \mathrm{L}\right)\end{array}$ & $7.8(5.2-8.7)$ & $8.1(4.9-9.3)$ & $7.1(4.5-9.2)$ & $7.3(5.0-9.7)$ & $7.2(4.9-10.4)$ & $7.6(5.6-9.0)$ \\
\hline $\begin{array}{l}\text { Eosinophils } \\
\qquad\left(10^{6} \text { cells } / \mathrm{L}\right)\end{array}$ & $88(22-297)$ & $198(22-352)$ & $264(99-473)$ & $308(231-1002)^{*}$ & $276(44-605) \dagger$ & $308(121-1496) \dagger$ \\
\hline $\mathrm{ECP}(\mathrm{ng} / \mathrm{ml})$ & $13.6(5.5-16.1)$ & $10.9(6.5-16.8)$ & $16.1(6.3-17.5)$ & $16.9(11.2-28.6)^{*}$ & $17.6(16.4-60.3) \ddagger$ & $17.8(15.9-45.1) \dagger$ \\
\hline
\end{tabular}

Values expressed as medians, with ranges in parentheses.

$* p \leq 0.02$ compared with 16:00 value within group.

FAll subjects with asthma at 16:00 and 04:00 hours, $p \leq 0.02$, compared with value of control group.

$\neq p \leq 0.03$ compared with $16: 00$ values for groups 1 and 2 .

asthma, with increased circadian PEF variation as compared with those without increased circadian PEF variation. A significant correlation was found between serum ECP and circadian PEF variation in subjects with asthma. In addition, a trend was observed toward a correlation between 16:00 hours BAL $\mathrm{PGD}_{2}$ levels and circadian PEF variation in subjects with asthma, but no correlation between the $\mathrm{TxB}_{2}$ levels and the circadian PEF variation existed. The results together suggest that increased NAN is more likely to occur in subjects with asthma with higher serum ECP and BAL $\mathrm{PGD}_{2}$ levels.

So far, contradictory results have been reported on the recruitment of leukocytes to the airways at night in nocturnal asthma. Martin et al. ${ }^{3}$ demonstrated significant increases in numbers of eosinophils and lymphocytes in BAL fluid in association with increases in total white blood cell counts and neutrophil counts. In contrast, Jarjour et al. ${ }^{4}$ did not find changes in BAL cell count in their subjects with nocturnal asthma, which corresponds with our findings. A comparison of patient characteristics of these two studies and ours shows that the subjects with nocturnal asthma in the study of Martin et al. generally had more severe asthma, with lower mean FEV $_{1}$ values and higher circadian $\mathrm{PEF}$ variations at home. It is therefore possible that only in severe NAN an association can be found with pronounced infiltration of inflammatory cells into the airways, as recovered by BAL fluid. Furthermore, in both of the other studies most of the subjects used theophylline at the time of investigation, whereas our subjects did not use theophylline and maintenance therapy was withheld from 4 weeks before the start of the study. Although Martin et al. reported that the mean serum theophylline concentrations at 16:00 and 04:00 hours did not differ, it is not clear whether individual differences in serum concentrations were observed. Changes in theophylline levels are known to modulate PB eosinophil numbers, ${ }^{25}$ and we do not exclude the possibility that this may have affected airway leukocyte traffic in their study as well.

Contradictory results have also been reported on variations of $\mathrm{PB}$ eosinophil numbers and their activity between 04:00 and 16:00 hours in subjects with nocturnal asthma. Because the eosinophil shows a circadian chronobiologic rhythm with the highest value at night around 2:00 AM in normal subjects, ${ }^{9}$ equal or increased numbers are likely to be found at night, depending on the time point of investigation. Eosinophil numbers in subjects with nocturnal asthma were reported to be either nor$\mathrm{mal}^{3}$ and increased ${ }^{5,6}$ at 4:00 AM, or decreased. ${ }^{7}$ In our study PB eosinophil numbers increased at night, without a difference between the three groups, whereas no variation in ECP levels between 04:00 and 16:00 hours was found in the group with increased circadian PEF variation. Fitzpatrick et al. ${ }^{7}$ reported decreased eosinophil counts, together with reduced serum ECP levels during the night and suggested these findings to be compatible with the involvement of a late asthmatic reaction in the pathogenesis of nocturnal asthma, although it cannot be excluded that the use of inhaled and oral corticosteroids in the latter study may have affected the results. ${ }^{6}$

Interestingly, subjects with asthma with increased circadian PEF variation could be distinguished from subjects with asthma without increased circadian PEF variation by significantly higher levels of $\mathrm{PGD}_{2}$ in BAL and ECP in serum at 16:00 hours, suggesting that increased nocturnal airway obstruction in subjects with asthma occurs in those subjects with a preexisting more severe degree of inflammation. $\mathrm{PGD}_{2}$ is the major pros- 


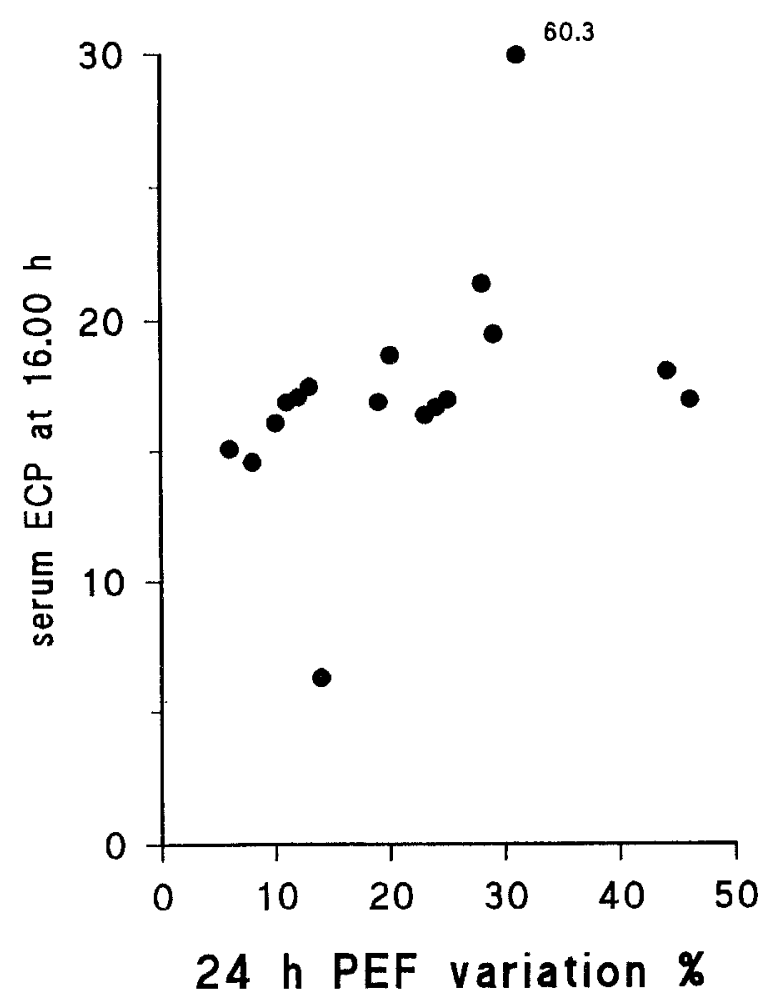

FIG. 3. Relationship between serum ECP levels at 16:00 hours and circadian PEF variation in all subjects with asthma $(r=0.61, p=0.01)$.

tanoid release product of mast cells, although other cells in the airways such as alveolar macrophages and eosinophils can synthesize $\mathrm{PGD}_{2}$ as well. ${ }^{26}$ Indirect evidence of a role for mast cell activation in nocturnal asthma has been suggested by findings that subjects with asthma with increased NAN showed a higher airway hyperresponsiveness to adenosine $5^{\prime}$-monophosphate, ${ }^{1}$ which exerts its airway constrictive effect mainly by mast cell activation. On adenosine 5 '-monophosphate provocation, $\mathrm{PGD}_{2}$ levels in the BAL fluid have been reported to be increased. ${ }^{27}$ Inhalation of a noncontractile dose of $\mathrm{PGD}_{2}$ has been shown to potentiate airway hyperresponsiveness to methacholine and histamine. ${ }^{28}$ Therefore release of $\mathrm{PGD}_{2}$ may play an important role in the increased airway hyperresponsiveness at night, underlying increased NAN in asthma.

Increased serum ECP levels in subjects with asthma with increased NAN were not accompanied by increased eosinophil activation in BAL fluid in our study. It is possible that measurement of eosinophil activation parameters in BAL fluid does not fully reflect eosinophil activation in the airways or only at a more severe stage of airway inflammation. Studies on biopsy specimens ob- tained from the bronchial wall may reveal additional information about the involvement of eosinophil activation in increased NAN in asthma.

In contrast to the observed circadian fluctuations in PB samples, we did not find evidence for circadian fluctuations in cell number and mediators in the BAL fluid. In healthy subjects the various $\mathrm{PB}$ cell types show different circadian rhythms, resulting in higher numbers of circulating lymphocytes and eosinophils and lower numbers of neutrophils during the night. ${ }^{9}$ These fluctuations were not found in the BAL cell numbers. BAL lymphocyte numbers did not change at night, whereas eosinophil numbers increased together with the neutrophil numbers in the control group and the asthma group without circadian PEF rhythm. However, we did not observe these changes in the asthma group with increased circadian PEF rhythm. Possibly these cells are entrapped at night in increased numbers in the airway mucosa in subjects with asthma with increased NAN. This assumption needs further investigation.

In conclusion, we found that increased NAN in subjects with asthma is on the whole not associated with a circadian fluctuation in cell number and inflammatory mediators in PB and BAL fluid. In general, higher numbers of eosinophils and levels of cell activation products are found in BAL fluid and PB from subjects with asthma as compared with control subjects. However, in subjects with asthma with increased nocturnal airways obstruction most activation parameters did not differentiate them from subjects with asthma without nocturnal airways obstruction. Interestingly, significantly higher levels of ECP in serum and $\mathrm{PGD}_{2}$ in BAL fluid were present in subjects with asthma with increased nocturnal airways obstruction. These findings suggest that increased NAN occurs in subjects with asthma with ongoing increased nonspecific cellular activation during the day.

We thank Mrs. T. A. van der Naald and Dr. E. J. M. Weersink for assistance during bronchoscopy, and Mrs. A. P. M. van Dijk for technical analysis of the eicosanoids.

\section{REFERENCES}

1. Oosterhoff Y, Koëter GH, De Monchy JGR, Postma DS. Circadian variation in airway responsiveness to methacholine, propranolol and AMP in atopic asthmatic subjects. Am Rev Respir Dis 1993;147:512-17.

2. Wempe JB, Tammeling EP, Postma DS, Auffarth B, Teengs JP, Koëter GH. Effect of budesonide and bambu- 
terol on diurnal variation of airway hyperresponsiveness and nocturnal symptoms of asthma. J ALLERGY CLIN IMMUNOL 1992;90:349-57.

3. Martin RJ, Cicutto LC, Smith HR, Ballard RD, Szefler SJ. Airways inflammation in nocturnal asthma. Am Rev Respir Dis 1991;143:351-7.

4. Jarjour NN, Busse WW, Calhoun WJ. Enhanced production of oxygen radicals in nocturnal asthma. Am Rev Respir Dis [992;146:905-11.

5. Calhoun WJ, Bates ME, Schrader L, Sedgwick JB, Busse WW. Characteristics of peripheral blood eosinophils in patients with nocturnal asthma. Am Rev Respir Dis 1992; 145:577-81.

6. Wempe JB, Tammeling EP, Koëter GH, Håkansson L, Venge P, Postma DS. Blood eosinophil numbers and activity during 24 hours: effects of treatment with budesonide and bambuterol. J ALLERGy Clin IMMUNOL 1992;90: 757-65.

7. Fitzpratrick MF, Mackay T, Walters C, et al. Circulating histamine and eosinophil cationic protein levels in nocturnal asthma. Clin Sci 1992;83:227-32.

8. Szeffer SJ, Ando R, Cicutto LC, Surs W, Hill MR, Martin RJ. Plasma histamine, epinephrine, cortisol, and leukocyte $\beta$-adrenergic receptors in nocturnal asthma. Clin Pharmacol Ther 1991;49:59-68.

9. Haus E, Lakatua DA, Swoyer J, Sackett-Lundeen L. Chronobiology in hematology and immunology. Am $\mathbf{J}$ Anat 1983;168:467-517.

10. Wardlaw AJ, Dunnett S, Gleich GJ, Collins JV, Kay AB. Eosinophils and mast cells in bronchoalveolar lavage in mild asthma: relationship to bronchial hyperactivity. Am Rev Respir Dis 1988;136:379-83.

11. Holgate ST, Hardy C, Robinson C, Agius RM, Howarth $\mathrm{PH}$. The mast cell as a primary effector cell in the pathogenesis of asthma. J ALLERGY CLIN IMMUNOL 1986;77:27482.

12. Marini M, Avoni E, Hollemborg J, Mattoli S. Cytokine mRNA profile and cell activation in bronchoalveolar lavage fluid from nonatopic patients with symptomatic asthma. Chest 1992;102:661-9.

13. Bousquet J, Chanez P, Lacoste JY, et al. Eosinophilic inflammation in asthma. N Engl J Med 1990;323:1033-9.

14. Broide DH, Gleich GJ, Cuomo AJ, et al. Evidence of ongoing mast cell and eosinophil degranulation in symptomatic asthma airway. J ALLERGY CLIN IMMUNOL 1991;88: 637-48.

15. Jarjour NN, Calhoun WJ, Schwartz LB, Busse WW. Elevated bronchoalveolar lavage fluid histamine levels in allergic asthmatics are associated with increased airway obstruction. Am Rev Respir Dis 1991;144:83-7.
16. Liu MC, Bleecker ER, Lichtenstein LM, et al. Evidence for elevated levels of histamine, prostaglandin $\mathrm{D}_{2}$, and other bronchoconstricting prostaglandins in the airways of subjects with mild asthma. Am Rev Respir Dis 1990;142:12632.

17. American Thoracic Society. Standards for the diagnosis and care of patients with COPD and asthma. Am Rev Respir Dis 1987;136:225-44.

18. Rijcken B, Schouten JP, Weiss ST, Speizer FE, Van der Lende $\mathrm{R}$. The relationship of nonspecific bronchial responsiveness to respiratory symptoms in a random population sample. Am Rev Respir Dis 1987;136:62-8.

19. Cockcroft DW, Killian DN, Mellon JJA, Hargreave FE. Bronchial reactivity to inhaled histamine: a method and clinical survey. Clin Allergy 1977;7:235-43.

20. Summary and recommendations of a workshop on the investigative use of fiberoptic bronchoscopy and bronchoalveolar lavage in asthmatics. Am Rev Respir Dis 1985;132: 180-2.

21. Tai PC, Spry CJF, Peterson C, Venge P, Olsson I. Monoclonal antibodies distinguish between storage and secreted forms of eosinophil cationic protein. Nature 1984;309: 182-4.

22. Peterson CGB, Enander I, Nystrand J, Anderson AS, Nilsson L, Venge P. Radioimmunoassay of human eosinophil cationic protein (ECP) by an improved method: establishment of normal levels in serum and turnover in vivo. Clin Exp Allergy 1991;21:561-7.

23. Carlson M, Håkansson L, Peterson C, Stălenheim G, Venge P. Secretion of granule proteins from eosinophils and neutrophils is increased in asthma. J ALLERGY CLIN IMMUNOL 1991;87:27-33.

24. Zijlstra FJ, Vincent JE, Mol WM, Hoogsteden HC, Van Hal PW, Jongejan RC. Eicosanoid levels in bronchoalveolar lavage fluid of young female smokers and nonsmokers. Eur J Clin Invest 1992;22:301-6.

25. Braat MCP, Jonkers RE, Bel EH, Van Boxtel CJ. Quantification of theophylline induced eosinopenia and hypokalaemia in healthy subjects. Clin Pharmacokinet 1992;22: 231-7.

26. Arm JP, Lee TH. The pathobiology of bronchial asthma. Adv Immunol 1992;51:323-82.

27. Polosa $\mathrm{R}, \mathrm{Ng} \mathrm{WH}$, Crimi $\mathrm{N}$, et al. Release of mast-cellderived mediators after endobronchial adenosine challenge in asthma. Am J Respir Crit Care Med 1995;151: 624-9.

28. Fuller RW, Dixon CMS, Dollery CT, Barnes PJ. Prostaglandin $\mathrm{D}_{2}$ potentiates airway responsiveness to histamine and methacholine. Am Rev Respir Dis 1986;133:252-4. 